\title{
Brain tumors and polyomaviruses
}

\author{
Sidney Croul, Jessica Otte, and Kamel Khalili \\ Center for Neurovirology and Cancer Biology, College of Science and Technology, Temple University, Philadelphia, \\ Pennsylvania, USA
}

\begin{abstract}
Polyomaviruses, including JC virus (JCV), BK virus (BKV), and simian virus 40 (SV40) have attracted much attention in the past decade due to their repeated isolation from various human tumors, including those originating from the central nervous system (CNS). JCV and BKV are considered to be ubiquitous human pathogens that become reactivated under impaired physiological conditions such as immunosuppression. Productive replication of JCV and BKV induces diseases such as progressive multifocal leukoencephalopathy in the brain and hemorrhagic or nonhemorrhagic cystitis and nephritis in the kidney. JCV DNA sequences have been isolated from a number of human CNS tumors, including medulloblastoma, ependymoma, and a broad range of glial-origin neoplasms. SV40, once believed to be a monkey virus, has now been isolated from a variety of human cancer cells, including mesothelioma, ependymoma, and non-Hodgkin's lymphoma. In this mini-review, the authors focused their attention on the possible involvement of polyomaviruses, such as JCV, BKV, and SV40, with human brain tumors. Journal of NeuroVirology (2003) 9, 173-182.
\end{abstract}

Keywords: cancer; oncogene; PML; T-antigen; tumorigenesis

\section{Introduction}

\section{Brain tumors}

New cases of brain tumors in humans are diagnosed annually in approximately 1 in 9000 people. In the adult population, they account for $9 \%$ to $10 \%$ of all primary tumors. In children, the annual incidence of tumors of the central nervous system (CNS) is about 3.7 cases per 100,000 , making it the second most common neoplastic disease in the pediatric population.

Classification of brain tumors is based on our current understanding of the cellular development of the nervous system. Neuronal precursors give rise to immature neoplasms known as primitive neuroectodermal tumors (PNETs), whereas glial precursors give rise to a wide range of tumors from various spe-

Address correspondence to Sidney Croul, Center for Neurovirology and Cancer Biology, College of Science and Technology, Temple University, 1900 North 12th Street, 015-96, Room 203, Philadelphia, PA 19122, USA. E-mail: sidney.croul@drexel.edu

The authors wish to thank past and present members of the Center for Neurovirology and Cancer Biology for their insightful discussion and sharing of ideas. The authors also thank C Schriver for preparation of this manuscript. This work was supported by grants awarded by the NIH to KK.

Received 22 December 2002; revised 2 January 2003; accepted 17 January 2003. cialized cellular subsets, including ependymocytes, astrocytes, and oligodendrocytes. The neural crest gives rise to the cells that form the peripheral nervous system and the meningeal coverings of both central and peripheral structures. In the peripheral nervous system, neural crest-derived tumors include schwannomas and neurofibromas, whereas the arachnoidal cells of the meninges give rise to meningiomas.

The major factors in disease severity, due to their location, are that brain tumors produce both focal and generalized disabilities. Many brain tumors, including gliomas, tend to widely infiltrate the CNS, making surgical cure virtually noneffective. In most cases, treatments are only palliative and long-term survival with most tumors is limited to a few years (Greenberg et al, 1999).

Our present knowledge of the causes of these tumors is limited. From an environmental perspective, ionizing radiation is an established risk factor, particularly at high doses. Nonionizing radiation may also be a risk factor as well, as attested to by an increased risk for brain tumor development in individuals who are routinely subjected to high electrical current flow. Chemical agents that have been implicated in brain tumorigenesis include $N$-nitroso compounds, tobacco, alcohol, and vinyl chloride. Occupational risk appears to be elevated for electricians, 
petrochemical workers, rubber tire fabricators, aircraft pilots, farmers, and health professionals. The degree to which these factors account for the total number of human brain tumors is not known but appears to be small (Davis and Preston-Martin, 1998).

An increase in brain tumors within families and the association of brain tumors with known genetic syndromes suggests a hereditary role for the development of brain tumors. Heritable syndromes with a predisposition for nervous system tumors include Turcot's syndrome, which is associated with astrocytomas, glioblastomas, and medulloblastomas; Gorlin's syndrome associated with medulloblastomas; neurofibromatosis type 1 associated with astrocytomas and optic nerve gliomas; and neurofibromatosis type II associated with multiple schwannomas, meningiomas, and neurofibromas. The relative risk of brain tumors in first and second degree relatives of affected patients may be as high as $8.9 \%$ (Bondy et al, 1994). Inherited predisposition may also account for $5 \%$ of all pediatric brain tumors (Bondy et al, 1991). Cytogenetic and molecular studies have identified numerous markers for brain tumors and implicated the involvement of specific pathways such as the p53/MDM2 pathway. Mutations in p53, the basis of the Li-Fraumeni syndrome, are also found in one-third of astrocytomas. The gene for MDM2, which interacts with p53, is amplified in $10 \%$ of astrocytomas. Similarly, unraveling Turcot's syndrome has placed emphasis on the wingless pathway leading to a mutated APC (adenomatous polyposis coli) gene, Gorlin's syndrome on the hedgehog/patched signaling pathway, and neurofibromatoses I and II on the gene products neurofibromin and merlin, respectively (Biegel, 1999; Nozaki et al, 1999).

Several studies have reported an increased risk of childhood brain tumors in individuals whose mothers were infected with various viruses during pregnancy (Adelstein and Donovan, 1972; Linet et al, 1996). One particular area of inquiry into the possibility of an infectious etiology of brain tumors comes from studies on polyomaviruses due to their established ability to transform cells in vitro and to induce tumors in experimental animals (Butel, 1997; Khalili, 2001).

\section{Polyomaviruses}

Human polyomaviruses, which include the wellstudied simian virus 40 (SV40), JC virus (JCV), and $\mathrm{BK}$ virus (BKV), are icosahedral nonenveloped DNA viruses with capsid diameters of approximately $45 \mathrm{~nm}$. The genome consists of covalently bound, double-stranded, circular supercoiled DNA with an average length of $5 \mathrm{~kb}$. The polyomaviral genomes have common structural features consisting of a noncoding regulatory region, an early region encoding the regulatory protein, $\mathrm{T}$ antigen, and its various isoforms, and a late region that encodes for the structural capsid proteins (Frisque and White, 1992).

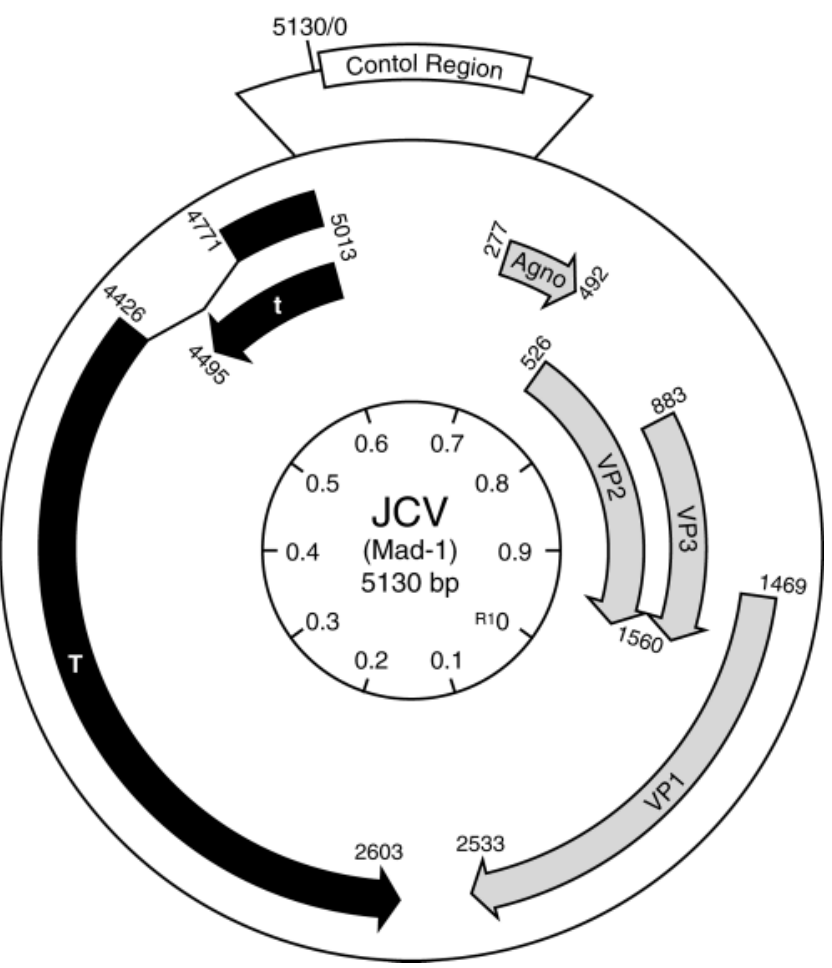

Figure 1 Organization of the polyoma genome. The genome of JCV is schematized as an exemplar. The circular genomes of all polyoma viruses are similar, with three general regions identified based on function. These comprise the regulatory (noncoding) region, the early coding region and the late coding region.

The regulatory region separates the coding regions and contains sequences that are necessary for the initiation of viral gene transcription and viral DNA replication. Transcription of the early and late genes proceeds in opposite directions around the viral DNA. Figure 1 illustrates the structural organization of the human neurotropic polyomavirus JCV genome.

In humans, JCV causes the subacute fatal CNS demyelinating disease progressive multifocal leukoencephalopathy (PML) due to productive infection of oligodendrocytes (for details, see the article by Seth et al [2003] in this issue). Although this rare syndrome was originally described in patients with systemic immunosuppression due to lymphoproliferative and myeloproliferative disorders and/or chemotherapy, it has subsequently been recognized as a concomitant of human immunodeficiency virus (HIV)-1 infection, accounting for a distinct rise in the incidence of PML in the acquired immunodeficiency syndrome (AIDS) population (Berger et al, 1998). BKV most commonly causes a self-limited hemorrhagic cystitis during pregnancy and has also been associated with urinary tract, respiratory tract, and meningeal inflammatory diseases in children, HIV-1-infected individuals, and transplant recipients (Arthur et al, 1986). SV40, although originally classified as a monkey polyomavirus, has recently been shown to infect humans as well. Serological 
surveillance of worldwide populations has led investigators to conclude that primary human polyomavirus infections are extremely common, occur during youth, and are often subclinical. Following acute infection, viral persistence over prolonged intervals has been demonstrated in brain, lung, kidney, bone, and blood by a variety of techniques, including Southern blotting and polymerase chain reaction (PCR) (Arthur et al, 1989).

These findings have suggested that many symptomatic polyoma infections represent reactivation in immunocompromised carriers and that the conditions under which these occur alter the ability of the organism to abrogate viral reproduction. Support for this notion stems from sequence analysis of JCV and BKV isolates. The regulatory regions of archetype strains cloned from healthy, asymptomatic individuals lack the large tandem repeats found in many of the isolates from symptomatic patients. This suggests an adaptation of the virus, including spontaneous alterations of the regulatory region following an initial infection with an archetype strain. This adaptation may allow for expression in tissue types such as brain or the urogenital tract under immunosuppressive conditions, which result in manifest pathologies such as PML and cystitis (Frisque and White, 1992).

\section{Polyomaviruses and human brain tumors}

The initial evidence that human brain tumors might be associated with polyoma virus infection came from retrospective analyses of tumor incidence versus SV40 polio vaccine contamination (Farwell et al, 1984, Heinonen et al, 1973). Although this hypothesis remains controversial, the rationale for a possible link emerged as a result of two concurrent research projects. During the initial manufacture of the Salk polio vaccine from 1954 to 1960 , the vaccine was grown on monolayers of rhesus monkey kidney cells, which were then treated with graded concentrations of formalin to inactivate virus infectivity while preserving antigenicity. Following the isolation of the SV40 virus in 1960, there was fairly rapid recognition of SV40 contamination of these lots because SV40 is found frequently in rhesus monkeys but is more resistant to formalin inactivation than polio. Concurrent with these studies were observations that SV40 could cause tumors when inoculated into animal species that were not the natural host. The range of tumors in these initial experiments included ependymomas produced by intracranial injections (Rabson et al, 1962) and sarcomas from intramuscular inoculations (Eddy et al, 1961). Although the administration of SV40-contaminated polio vaccine was eliminated by 1961 , it is not known how many of the 90 million people who were given the Salk vaccine were exposed to SV40. Estimates of between 10 and 30 million people have been made (Shah and Nathanson, 1976).

Along with the epidemiologic evidence, case reporting and pathologic analyses initially strengthened the association of polyomaviruses with human
CNS tumors as summarized in Table 1. The first evidence for polyoma involvement in choroid plexus tumors came from the electron microscopic observation of viral particles most consistent with polyoma virus in surgically excised papilloma from a 33year-old woman (Bastian, 1971). Gliomas and CNS lymphomas coexisting in the brains of patients with PML provided a link between JCV and these tumors (Castaigne et al, 1974; GiaRusso and Koeppen, 1978). In particular, the histopathology of PML is suggestive of astrocytic neoplasias in that the "bizarre astrocytes" typically observed in PML lesions are thought to resemble the transformed cells of glioblastoma. Although JCV infection of oligodendrocytes that express both $\mathrm{T}$ antigen and capsid protein is lytic, astrocytes may be non- or semipermissive for JCV. In this setting, expression of $\mathrm{T}$ antigen in the absence of lytic infection may alter the cell cycle, resulting in tumors of astrocytic origin.

\section{SV40 detection in human brain tumors}

Using anti-SV40 T-antigenantibody, the polyomavirus early protein, $\mathrm{T}$ antigen, was first observed in human brain tumors by immunohistochemical analysis (Tabuchi et al, 1978). Further investigation using Southern blotting revealed the presence of episomal SV40 DNA in human CNS tumors (Krieg et al, 1981). This has subsequently been confirmed in studies employing PCR amplification of archival specimens (Huang et al, 1999; Weggen et al, 2000). Similar sequences have also been detected in a more mature neuronal tumor, the ganglioneuroma (Lednicky et al, 1995). Historically, the molecular evidence for SV40 in human glial tumors has been investigated most extensively in ependymal tumors. Both Southern blotting and PCR amplification have been used to analyze these tumors and demonstrate a large number with sequences specific for SV40 and JCV (Bergsagel et al, 1992; Huang et al, 1999; Lednicky et al, 1995; Martini et al, 1996). An initial analysis of amplified SV40 sequences revealed an archetype arrangement of the enhancer region (Lednicky et al, 1995). This finding raised the possibility that the archetype sequence might confer some degree of tissue specificity and increase the likelihood of tumor formation. A more intensive analysis performed on a number of these cases from which full-length polyoma sequences could be amplified suggests that SV40 has a relatively broad host and tissue range and that the archetype sequence can be found in both tumorous and nontumorous sources (Stewart et al, 1998). These studies and others demonstrate SV40 sequences in other glial tumors, including choroid plexus tumors, low grade astrocytomas, malignant astrocytomas, and oligodendrogliomas (Bergsagel et al, 1992; Huang et al, 1999; Kouhata et al, 2001; Kreig et al, 1981; Krieg and Scherer 1984; Lednicky et al, 1995, Malkin et al, 2001; Martini et al, 1996; Meinke et al, 1979). Furthermore, SV40 sequences have been detected in meningiomas, which are 
Table 1 Association of human brain tumors with polyomaviruses

\begin{tabular}{|c|c|c|c|}
\hline Polyomavirus & Tumor histology & References & Methodologies employed \\
\hline \multirow[t]{34}{*}{ SV40 } & \multirow{4}{*}{ Astrocytoma } & Huang et al, 1999 & PCR \\
\hline & & Kreig et al, 1981 & Southern blot \\
\hline & & Kreig and Scherer 1984 & Sequencing \\
\hline & & Martini et al, 1996 & PCR \\
\hline & Anaplastic astrocytoma & Huang et al, 1999 & PCR \\
\hline & Gemistocytic astrocytoma & Huang et al, 1999 & PCR \\
\hline & \multirow[t]{3}{*}{ Glioblastoma } & Kouhata et al, 2001 & PCR \\
\hline & & Martini et al, 1996 & PCR \\
\hline & & Meinke et al, 1979 & Southern blot \\
\hline & Giant cell glioblastoma & Huang et al, 1999 & PCR \\
\hline & Gliosarcoma & Huang et al, 1999 & PCR \\
\hline & \multirow{2}{*}{ Oligodendroglioma } & Huang et al, 1999 & PCR \\
\hline & & Kreig et al, 1981 & Southern blot \\
\hline & \multirow[t]{5}{*}{ Ependymoma } & Bergsagel et al, 1992 & PCR \\
\hline & & Huang et al, 1999 & PCR \\
\hline & & Lednicky et al, 1995 & PCR and sequencing \\
\hline & & Martini et al, 1996 & PCR \\
\hline & & Weggen et al, 2000 & PCR \\
\hline & Malignant ependymoma & Tabuchi et al, 1978 & IHC \\
\hline & Subependymoma & Weggen et al, 2000 & PCR \\
\hline & \multirow[t]{5}{*}{ Choroid plexus papilloma } & Bergsagel et al, 1992 & PCR \\
\hline & & Lednicky et al, 1995 & PCR and sequencing \\
\hline & & Malkin et al, 2001 & PCR and IHC \\
\hline & & Martini et al, 1996 & PCR \\
\hline & & Tabuchi et al, 1978 & IHC \\
\hline & \multirow[t]{2}{*}{ Choroid plexus carcinoma } & Lednicky et al, 1995 & PCR and sequencing \\
\hline & & Malkin et al, 2001 & PCR and IHC \\
\hline & \multirow{4}{*}{ Meningioma } & Kreig et al, 1981 & Southern blot \\
\hline & & Kreig and Scherer, 1984 & Sequencing \\
\hline & & Martini et al, 1996 & PCR \\
\hline & & Weggen et al, 2000 & PCR \\
\hline & \multirow[t]{2}{*}{ Medulloblastoma } & Kreig et al, 1981 & Southern blot \\
\hline & & Weggen et al, 2000 & PCR \\
\hline & Ganglioneuroma & Lednicky et al, 1995 & PCR and sequencing \\
\hline \multirow[t]{22}{*}{ JCV } & \multirow[t]{2}{*}{ Astrocytoma } & Caldarelli-Stefano et al, 2000 & PCR and IHC \\
\hline & & Del Valle et al, 2001 & PCR and IHC \\
\hline & Anaplastic astrocytoma & Del Valle et al, 2001 & PCR and IHC \\
\hline & \multirow[t]{3}{*}{ Glioblastoma } & De Valle et al, 2000 & PCR and IHC \\
\hline & & Del Valle et al, 2001 & PCR and IHC \\
\hline & & Del Valle et al, 2002 & PCR and IHC \\
\hline & Gliosarcoma & Del Valle et al, 2001 & PCR and IHC \\
\hline & Pilocytic astrocytoma & Del Valle et al, 2001 & PCR and IHC \\
\hline & Pleomorphic xanthoastrocytoma & Boldorini et al, 1998 & PCR \\
\hline & \multirow[t]{2}{*}{ Oligodendroglioma } & Caldarelli-Stefano et al, 2000 & PCR and IHC \\
\hline & & Del Valle et al, 2001 & PCR and IHC \\
\hline & Anaplastic oligodendroglioma & Del Valle et al, 2001 & PCR and IHC \\
\hline & \multirow[t]{2}{*}{ Oligoastrocytoma } & Del Valle et al, 2001 & PCR and IHC \\
\hline & & Rencic et al, 1996 & PCR, IHC, and Western blot \\
\hline & Ependymoma & Caldarelli-Stefano et al, 2000 & PCR and IHC \\
\hline & & Del Valle et al, 2001 & PCR and IHC \\
\hline & Subependymoma & Del Valle et al, 2001 & PCR and IHC \\
\hline & Meningioma & Weggen et al, 2000 & PCR \\
\hline & Medulloblastoma & Del Valle et al, 2002 & PCR and IHC \\
\hline & & Khalili et al, 1999 & PCR and IHC \\
\hline & & Krynska et al, 1999 & PCR and IHC \\
\hline & Gliomatosis cerebri & Del Valle et al, 2001 & PCR and IHC \\
\hline BKV & Astrocytoma & Corallini et al, 1987b & Southern blot and sequencing \\
\hline & Glioblastoma & Corallini et al, 1987b & Southern blot and sequencing \\
\hline & & Dörries et al, 1987 & Southern blot \\
\hline & Oligodendroglioma & Corallini et al, 1987b & Southern blot and sequencing \\
\hline & & Dörries et al, 1987 & Southern blot \\
\hline & Ependymoma & Corallini et al, 1987b & Southern blot and sequencing \\
\hline & Meningioma & Corallini et al, 1987b & Southern blot and sequencing \\
\hline & & Dörries et al, 1987 & Southern blot \\
\hline & Schwannoma & Corallini et al, 1987b & Southern blot and sequencing \\
\hline & & Dörries et al, 1987 & Southern Blot \\
\hline
\end{tabular}

Each human polyomavirus has been associated with human tumors, particularly those originating in the CNS. The positive published findings for human brain tumors are enumerated in this table by virus, tumor type, and the detection methods that have been employed successfully. 
believed to originate from cells of neural crest origin (Kreig et al, 1981; Krieg and Scherer, 1984; Martini et al, 1996; Weggen et al, 2000).

\section{$B K V$ detection in human brain tumors}

In two separate studies (Corallini et al, 1987b; Dörries et al, 1987), BKV sequences have been detected in ependymomas, astrocytomas, both benign and malignant, oligodendrogliomas, meningiomas, and schwannomas. Additional research has detected BKV in more than $85 \%$ of CNS cell lines (De Mattei et al, 1995).

\section{JCV detection in human brain tumors}

Investigations of JCV in human brain tumors have employed molecular amplification of the viral DNA and examination of viral gene expression. In a set of 23 primitive neuroectodermal origin tumors, i.e., medulloblastomas, 20 demonstrated N-terminal T-antigen sequences, 13 contained C-terminal T-antigen sequences, and 20 had sequences from the VP1 region (Khalili et al, 1999; Krynska et al, 1999a). In a subset of 16 of these tumors, further PCR analysis demonstrated sequences that code for the viral accessory protein, Agnoprotein. Immunohistochemistry has demonstrated $\mathrm{T}$ antigen in the nuclei of $25 \%$ of these tumors. Surprisingly, the Agnoprotein is detectable in the perinuclear cytoplasmic compartment in $55 \%$ of cases, frequently in the absence of $\mathrm{T}$ antigen. The VP late proteins were not detected in any of these cases (Del Valle et al, 2002). As with SV40, JCV sequences have been detected in a variety of both low- and high-grade glial tumors, including those of ependymal, astrocytic, and oligodendroglial origin (Boldorini et al, 1998; Caldarelli-Steffano et al, 2000; Del Valle et al, 2000, 2001; Rencic et al, 1996). In a survey of 85 glial tumors conducted in our laboratory, JCV early sequences were detected in $69 \%$ of samples by PCR and $33 \%$ of the tumors showed immunohistochemical evidence of T-antigen expression (Del Valle et al, 2001). As in the case of SV40, JCV sequences were detected in meningiomas as well (Weggen et al, 2000).

Tumors induced in experimental animal models Since the initial descriptions of SV40-induced tumors (Eddy et al, 1961; Rabson et al, 1962), a body of work has accumulated in a variety of experimental systems, expanding the role of polyomavirus in CNS tumors, as summarized in Table 2. Inoculation studies with SV40 produced lymphoma, leukemia, and sarcomas with intravenous injections of virus (Diamandopoulos, 1972). Mesotheliomas have resulted from intrapleural, intraperitoneal, and intracardiac injections of virus (Rizzo et al, 2001). BKV is only weakly oncogenic when inoculated into rodents subcutaneously but induces tumors in $70 \%$ to $80 \%$ of hamsters when injected intracerebrally or intravenously. Although the majority of tumors are ependymomas, pancreatic islet tumors, and osteosarcomas, occasional neuroblastomas, pineal tumors and fibrosarcomas are produced as well. Mice and rats develop a slightly different spectrum of tumors characterized by fibrosarcoma, liposarcoma, osteosarcoma, nephroblastoma, glioma, and choroid plexus papilloma (Corallini et al, 1987a; Dougherty, 1976; Shah et al, 1975; Uchida et al, 1979; Watanabe et al, 1982). JCV has been similarly implicated in experimental tumorigenesis of the nervous system. Inoculation of JCV intracerebrally into newborn Golden Syrian hamsters produces CNS tumors in more than $85 \%$ of the animals. The most common tumors found are primitive neuroectodermal tumors (PNETs), including medulloblastomas and pineocytomas (ZuRhein, 1983). Astrocytomas, glioblastomas, and peripheral neuroblastomas are

Table 2 Experimental brain tumors produced by human polyomavirus inoculation

\begin{tabular}{|c|c|c|c|}
\hline Polyomavirus & Species & Tumor histology & References \\
\hline \multirow[t]{3}{*}{ SV40 } & Hamster & Ependymoma & Eddy et al, 1962 \\
\hline & Rat & Ependymoma & Rabson et al, 1962 \\
\hline & Mouse & Choroid plexus papilloma & Brinster et al, 1984; Van Dyke et al, 1987 \\
\hline \multirow[t]{12}{*}{ JCV } & Monkey & Astrocytoma & London et al, 1978 \\
\hline & & Glioblastoma multiforme & London et al, 1978 \\
\hline & Hamster & Astrocytoma & ZuRhein, 1983 \\
\hline & & Ependymoma & ZuRhein, 1983 \\
\hline & & Medulloblastoma & ZuRhein, 1983 \\
\hline & & Pineocytoma & ZuRhein, 1983 \\
\hline & & Primitive neuroectodermal & ZuRhein, 1983 \\
\hline & Rat & Primitive neuroectodermal & Ohsumi et al, 1985 \\
\hline & Mouse & Adrenal neuroblastoma & Small et al, 1986; Franks et al, 1996 \\
\hline & & Medulloblastoma & Krynska et al, 1999b \\
\hline & & Malignant peripheral nerve sheath & Gordon et al, unpublished observations \\
\hline & & Pituitary adenoma & Gordon et al, 2000 \\
\hline \multirow[t]{2}{*}{ BKV } & Hamster & Ependymoma & $\begin{array}{l}\text { Corallini et al, 1987a; Dougherty 1976; } \\
\text { Uchida et al, 1979; Watanabe et al, } 1982\end{array}$ \\
\hline & Mouse & Ependymoma & Corallini et al, 1987a \\
\hline
\end{tabular}

The human polyomaviruses SV40, JCV, and BK have each produced a spectrum of brain tumors that are tabulated here. 
also commonly seen in the hamster model. Of interest, JCV is the only human virus known to induce solid tumors in nonhuman primates, as owl and squirrel monkeys injected intracerebrally with JCV develop astrocytomas (London et al, 1978).

In these experimental animals, $\mathrm{T}$ antigen can be detected in the absence of viral capsid protein expression (Frisque and White, 1992). Although SV40 has been isolated from transformed cells (Soriano et al, 1974), there has been only one report to date of infectious JCV recovery from an experimental animal (Major et al, 1987). In this instance, a JCV-induced glioblastoma detected in an owl monkey was cocultured with permissive human fetal glial cells, resulting in virion production. The inference drawn from these studies is that many tissue types may be infected with JCV, and their intracellular environments may permit early but not late gene expression, therefore not allowing the production of complete virus. T-antigen expression in the absence of late gene products may result in cell cycle dysregulation without cellular lysis leading to the expansion of these infected cells and their resulting transformation.

Further evidence for the direct association of $\mathrm{T}$ antigen with tumors of the nervous system emerges from studies of transgenic mice containing the polyoma early but not late genes. These animals constitutively produce early proteins under the control of the natural viral promoter/enhancer region in the absence of the influence of any late genes or gene products. Due to restrictions in lytic infection believed to occur upon infection of human polyomaviruses in rodent models, the use of early gene constructs lacking the late gene sequences may recapitulate the situation seen in abortive infections in human. SV40 transgenic mice have developed choroid plexus papillomas (Brinster et al, 1984; Messing et al, 1988; Van Dyke et al, 1987), whereas JCV transgenic mouse lines have developed medulloblastomas, peripheral neuroectodermal origin tumors including adrenal neuroblastomas and primitive mesenteric tumors, pituitary adenomas, and malignant peripheral nerve sheath tumors (Franks et al, 1996; Gordon et al, 2000; Gordon et al, unpublished observations, Krynska et al, 1999b; Small et al, 1986).

\section{Mechanisms of polyomavirus-induced CNS tumorigenesis}

The evidence from both human and experimental systems suggests that the oncogenecity of polyomavirus $\mathrm{T}$ antigens is due at least in part to their ability to bind and functionally inactivate cellular tumor suppressor proteins, including p53, and the retinoblastoma gene product $\mathrm{pRb}$ (Dyson et al, 1990). These two phosphoproteins normally affect cell growth and differentiation via control of the cell cycle. Deregulation of this function can result in uncontrolled cellular proliferation, setting the stage for tumorigenesis. It is worth noting that p53 was initially characterized by its ability to bind to SV40 $\mathrm{T}$ antigen (Levine, 1997) and has been shown to be stabilized by cells transformed by SV40. The association of $\mathrm{T}$ antigen with p53 may block the induction of p21/WAF-1, which normally contributes to the G1 stabilization of the cell cycle. Low levels of p21/WAF-1 can release the inhibition on the activity of cyclin:cdk complexes, which leads to phosphorylation of $\mathrm{pRb}$. Whereas in G1-arrested cells, hypophosphorylated $\mathrm{pRb}$ binds to the transcriptional regulator E2F-1, hyperphosphorylated pRb cannot complex with E2F-1. The liberation of E2F-1 may also be accomplished by the direct interaction of $\mathrm{T}$ antigen with $\mathrm{pRb}$. An increase in the cellular level of E2F-1 may lead to induction of its own gene expression and expression of other S phase-specific promoters such as proliferating cell nuclear antigen (PCNA), promoting entry of cells into S phase.

Although the scheme outlined above has helped us elucidate a large number of pathways involved in polyoma tumorigenesis, other lines of evidence should be considered as well. For instance, SV40 $\mathrm{T}$ antigen has been shown to be capable of regulating p53-mediated transcription in the absence of a direct interaction with p53 (Rushton et al, 1997). Interestingly, SV40 T antigen interacts with the hyperphosphorylated forms of the $\mathrm{pRb}$ family members $\mathrm{p} 130$ and p107, rather than with the hypophosphorylated form as in the case of $\mathrm{pRb}$. In addition, $\mathrm{T}$ antigen may also change the phosphorylation state of p107 and p130 (Knudsen and Wang, 1998). Furthermore, BKV $\mathrm{T}$ antigen has been shown to induce E2F-1 in the absence of $\mathrm{T}$ antigen binding to $\mathrm{pRb}$ (Harris et al, 1998).

The role of two additional signaling mechanism, the Wnt/wingless and insulin-like growth factor I receptor (IGF-IR) pathways, in relation to $\mathrm{T}$ antigenmediated cellular transformation has recently been explored. The Wnt signaling pathway plays a crucial role in a number of developmental processes, including neurogenesis, through a family of shortrange signaling molecules (Cadigan and Nusse, 1997). Signaling in this pathway revolves around a number of key molecules, including adenomatous polypopsis coli (APC) and $\beta$-catenin. In the absence of Wnt signaling, $\beta$-catenin is targeted for rapid degradation by the ubiquitin-proteasome pathway, whereas in the presence of Wnt signaling, $\beta$-catenin is hypophosphorylated and stabilized (Staib et al, 1996). $\beta$-Catenin then accumulates in cells and translocates to the nucleus where it binds to the T-cell factor (TCF)/lymphoid enhancer-binding factor (LEF) family of transcription factor. Formation of the $\beta$-catenin:LEF complex results in interaction with specific DNA sequences (5'-CCTTTGAACT$3^{\prime}$ ) positioned in the promoters of Wnt-responsive genes, including cell cycle regulators such as myc and cyclin D, as well as transcription of genes involved in cell growth, including c-myc and cyclin D (Behrens et al, 1996). In this respect, $\beta$-catenin plays a 
central role in regulating this pathway. Somatic mutations in APC, which typically lead to a truncated protein with no regulatory activity, can cause the accumulation of free $\beta$-catenin, and mutations in $\beta$ catenin itself have also been detected in greater than $4 \%$ of medulloblastomas (Huang et al, 2000). These mutations may increase the half-life of $\beta$-catenin, allowing free $\beta$-catenin to translocate to the nucleus. The accumulation of $\beta$-catenin has also been associated with mutational inactivation of p53 (Wetmore et al, 2001). Of note, in a murine medulloblastoma cell line derived from JCV T antigen-transgenic mice, T-antigen expression was associated with higher levels of cellular $\beta$-catenin (Gan et al, 2001). These observations suggests that the interaction between $\mathrm{T}$ antigen and $\beta$-catenin may play an important role in regulating cellular growth in vitro and in vivo.

The IGF-IR system has been implicated in the growth of normal and transformed cells, acting through its intermediate, insulin receptor substrate-1 (IRS-1). Both human and JCV T antigen-transgenic medulloblastomas grossly over express IRS-1. In addition, when human and transgenic medulloblastoma cell lines are exposed to IGF-I, phosphorylation of IGF-IR and IRS-1 occurs with concomitant cell proliferation. Both of these responses, as well as anchorage-independent growth of $\mathrm{T}$ antigentransformed medulloblastoma cells, are strongly inhibited by a dominant-negative mutant of the IGF-IR (Lassak et al, 2002; Wang et al, 2001). T antigen may well contribute to these observed effects in that translocation of IRS-1 to the nucleus has been observed in $\mathrm{T}$ antigen-positive human medulloblastoma biopsies and in JCV T antigen-transgenic mouse tumors. These results suggest that the IGF-IR system itself and in concert with JCV T antigen may play a role in these tumors.

In addition to cell cycle dysregulation, polyomaviruses may contribute to genetic instability. In support of this notion, SV40 T antigen has been associated with chromosomal instability of human fibroblast cell lines in vitro and JCV infection with chromosomal abnormalities in vivo (Neel et al, 1996; Ray et al, 1990). In addition, abnormal DNA repair has been observed in cells possessing the SV40 origin of replication and a portion of the early genes in the absence of T antigen (Hunter and Gurney, 1994). SV40 small $\mathrm{T}$ antigen itself can dysregulate the cell cycle of normal human fibroblasts (Gaillard et al, 2001). In more recent studies, an increase in telomerase activity and induction of Notch-1 upon infection of cells with SV40 suggest the potential involvement of additional regulatory pathways in response to polyomavirus infection (Foddis et al, 2002).

Of interest is the observation that expression of $\mathrm{T}$ antigen in human biopsies and tissues from a number of transgenic models is not detected in all tumor cells. Indeed, it is not clear that long-term maintenance of T-antigen expression is required beyond the initiation stage for continued tumor growth and progression to malignancy. In SV40 transgenic mice, $\mathrm{T}$ antigen can be detected in tissues prior to the appearance of tumors, whereas only a proportion of preneoplastic foci that express $\mathrm{T}$ antigen become fullfledged tumors (Van Dyke et al, 1987). In transgenic mice expressing SV40 T antigen under the control of an inducible promoter, silencing T-antigen expression after the creation of hyperplastic foci failed to stop the progress of tumor development, and in at least two different experimental systems involving SV40 and JCV, spontaneous loss of T-antigen has been associated with concomitant mutations in p53 (Ewald et al, 1996; Krynska et al, 2000; Salewski et al, 1999). These observations suggest that $\mathrm{T}$ antigen may operate via a "hit-and-run" mechanism whereby T-antigen expression in dysplastic cells or preneoplastic lesions may result in chromosomal instability or gene inactivation at an earlier stage of transformation, rendering T-antigen expression unnecessary for tumor maintenance.

\section{Perspectives}

The evidence accumulated over the last 40 years clearly associates polyomavirus infection with brain tumors. The $\mathrm{T}$ antigen of polyomaviruses with its transforming ability has been a powerful tool in unraveling several molecular pathways involved in the control of cell proliferation, including the cell cycle, Wnt and IGF signaling pathways, as well as many others. Although laboratory and animal studies have provided crucial information on polyomavirus-mediated tumorigenesis in the brain, the remaining challenge rests on the demonstrations of whether polyomaviruses may function as the etiologic agent of brain tumors in the human population or acts as a cofactor. In any event, due to the ability of viral proteins to deregulate many important biological events that can lead to cancer development, one must take seriously the observed association of this group of viruses with human cancers and put efforts in blocking its direct and/or indirect contributions to cancer development in the brain.

\section{References}

Adelstein AM, Donovan JW (1972). Malignant disease in children whose mothers had chickenpox, mumps, or rubella in pregnancy. BMJ 4: 629-631.

Arthur RR, Dagostin S, Shah KV (1989). Detection of BK virus and JC virus in urine and brain tissue by the polymerase chain reaction. J Clin Microbiol 27: 1174-1179. 
Arthur RR, Shah KV, Baust SJ, Santos GW, Saral R (1986). Association of BK viruria with hemorrhagic cystitis in recipients of bone marrow transplants. NEngl JMed 315: 230-234.

Bastian FO (1971). Papova-like virus particles in a human brain tumor. Lab Invest 25: 169-175.

Behrens J, von Kries JP, Kuhl M, Bruhn L, Wedlich D, Grosschedl R, Birchmeier W (1996). Functional interaction of beta-catenin with the transcription factor LEF-1. Nature 382: 638-642.

Berger JR, Pall L, Lanska D, Whiteman M (1998). Progressive multifocal leukoencephalopathy in patients with HIV infection. I NeuroVirol 4: 59-68.

Bergsagel DJ, Finegold MJ, Butel JS, Kupsky WJ, Garcea RL (1992). DNA sequences similar to those of simian virus 40 in ependymomas and choroid plexus tumors of childhood. N Engl J Med 326: 988-993.

Biegel JA (1999). Cytogenetics and molecular genetics of childhood brain tumors. Neuro-oncol 1: 139-151.

Boldorini R, Caldarelli-Stefano R, Monga G, Zocchi M, Mediati M, Tosoni A, Ferrante P (1998). PCR detection of JC virus DNA in the brain tissue of a 9-year-old child with Pleomorphic xanthoastrocytoma. J NeuroVirol 4: 242-245.

Bondy ML, Lustbader ED, Buffler PA, Schull WJ, Hardy RJ, Strong LC (1991). Genetic epidemiology of childhood brain tumors. Genet Epidemiol 8: 253-267.

Bondy M, Wiencke J, Wrensch M, Kyritsis AP (1994). Genetics of primary brain tumors: a review. J Neurooncol 18: $69-81$.

Brinster RL, Chen HY, Messing A, van Dyke T, Levine AJ, Palmiter RD (1984). Transgenic mice harboring SV40 T-antigen genes develop characteristic brain tumors. Cell 37: 367-379.

Butel JS, Lednicky JA, Stewart AR, Garcea RL, Finegold MJ (1997). SV40 and human brain tumors. J NeuroVirol 3(Suppl 1): S78-S79.

Cadigan KM, Nusse R (1997). Wnt signaling: a common theme in animal development. Genes Dev 11: 32863305.

Caldarelli-Stefano R, Boldorini R, Monga G, Meraviglia E, Zorini EO, Ferrante P (2000). JC virus in human glialderived tumors. Hum Pathol 31: 394-395.

Castaigne P, Randot P, Escourolle JL, Ribadeau D, Cathala F, Hauw J (1974). Leucoencephalothie multifocale progressive et "gliomes" multiples. Rev Neurol 130: 379-392.

Corallini A, Pagnani M, Viadana P, Camellin P, Caputo A, Reschiglian P, Rossi S, Altavilla G, Selvatici R, BarbantiBrodano G (1987a). Induction of malignant subcutaneous sarcomas in hamsters by a recombinant DNA containing BK virus early region and the activated human c-Harvey-ras oncogene. Cancer Res 47: 6671-6677.

Corallini A, Pagnani M, Viadana P, Silini E, Mottes M, Milanesi G, Gerna G, Vettor R, Trapella G, Silvani V, et al (1987b). Association of BK virus with human brain tumors and tumors of pancreatic islets. Int J Cancer 39: 60-67.

Davis FG, Preston-Martin S (1998). Epidemiology: incidence and survival In: Russell $\&$ Rubinstein's pathology of tumors of the nervous system, 6th ed. Bigner DD, McLendon RE, Bruner JM (eds). New York: Oxford University Press, pp 5-45.

Del Valle L, Azizi SA, Krynska B, Enam S, Croul SE, Khalili K (2000). Reactivation of human neurotropic JC virus expressing oncogenic protein in a recurrent glioblastoma multiforme. Ann Neurol 48: 932-936.
Del Valle L, Enam S, Lara C, Ortiz-Hidalgo C, Katsetos CD, Khalili K (2002). Detection of JC polyomavirus DNA sequences and cellular localization of T-antigen and agnoprotein in oligodendrogliomas. Clin Cancer Res 8: 33323340.

Del Valle L, Gordon J, Assimakopolou M, Katsetos C, Croul SE, Khalili K (2001). Detection of JC virus DNA sequences and expression of the viral regulatory protein, T-antigen, in tumors of the central nervous system. Cancer Res 61: 4287-4293.

De Mattei M, Martini F, Corallini A, Gerosa M, Scotlandi K, Carinci P, Barbanti-Brodano G, Tognon M (1995). High incidence of $\mathrm{BK}$ virus large-T-antigen-coding sequences in normal human tissues and tumors of different histotypes. Int J Cancer 61: 756-760.

Diamandopoulos GT (1972). Leukemia, lymphoma, and osteosarcoma induced in the Syrian golden hamster by simian virus 40. Science 176: 173-175.

Dörries K, Loeber G, Meixensberger J (1987). Association of polyomaviruses JC, SV40, and BK with human brain tumors. Virology 160: 268-270.

Dougherty RM (1976). Induction of tumors in Syrian hamsters by a human renal papovavirus, RF strain. J Natl Cancer Inst 57: 395-400.

Dyson N, Bernards R, Friend SH, Gooding LR, Hassell JA, Major EO, Pipas JM, Vandyke T, Harlow E (1990). Large T-antigens of many polyomaviruses are able to form complexes with the retinoblastoma protein. Virology 64: 1353-1356.

Eddy BE, Borman GS, Berkelet WH, Young RD (1961). Tumors induced in hamsters by injection of rhesus monkey kidney cell extracts. Proc Soc Exp Biol Med 191197.

Ewald D, Li M, Efrat S, Auer G, Wall RJ, Furth PA, Hennighausen L (1996). Time-sensitive reversal of hyperplasia in transgenic mice expressing SV40 T-antigen. Science 273: 1384-1386.

Farwell JR, Dohrmann GJ, Flannery JT (1984). Medulloblastoma in childhood: an epidemiological study. J Neurosurg 61: 657-664.

Foddis R, De Rienzo A, Broccoli D, Bocchetta M, Stekala E, Rizzo P, Tosolini A, Grobelny JV, Jhanwar SC, Pass HI, Testa JR, Carbone M (2002). SV40 infection induces telomerase activity in human mesothelial cells. Oncogene 21: 1434-1442.

Franks RR, Rencic A, Gordon J, Zoltick PW, Curtis M, Knobler RL, Khalili K (1996). Formation of undifferentiated mesenteric tumors in transgenic mice expressing human neurotropic polyomavirus early protein. Oncogene 12: 2573-2578.

Frisque RJ, White FA III (1992). The molecular biology of JC virus, causative agent of progressive multifocal leukoencephalopathy. In: Molecular neurovirolgy. Roos RP (ed). Totowa, NJ: Humana Press, pp 25-158.

Gaillard S, Fahrbach KM, Parkati R, Rundell K (2001). Overexpression of simian virus 40 small-T-antigen blocks centrosome function and mitotic progression in human fibroblasts. J Virol 75: 9799-9807.

Gan DD, Reiss K, Carrill T, Del Valle L, Croul S, Giordano A, Fishman P, Khalili K (2001). Involvement of Wnt signaling pathway in murine medulloblastoma induced by human neurotropic JC virus. Oncogene 20: 48644870 .

GiaRusso, MH, Koeppen AH (1978). Atypical progressive multifocal leukoencephalopathy and primary cerebral malignant lymphoma. J Neurol Sci 35: 391-398. 
Gordon J, Del Valle L, Otte J, Khalili K (2000). Pituitary neoplasia induced by expression of human neurotropic polyomavirus, JCV, early genome in transgenic mice. Oncogene 19: 4840-4846.

Greenberg HS, Chandler WF, Sandler HM (1999). Brain tumors: Contemporary neurology series, vol. 54. New York: Oxford University Press.

Harris KF, Christensen JB, Radany EH, Imperiale MJ (1998). Novel mechanisms of E2F induction by BK virus largeT-antigen: requirement of both the $\mathrm{pRb}$-binding and the J domains. Mol Cell Biol 18: 1746-1756.

Heinonen OP, Shapiro S, Monson RR, Hartz SC, Rosenberg L, Slone D (1973). Immunization during pregnancy against poliomyelitis and influenza in relation to childhood malignancy. Int J Epidemiol 2: 229-235.

Huang H, Mahler-Araujo BM, Sankila A, Chimelli L, Yonekawa Y, Kleihues P, Ohgaki H (2000). APC mutations in sporadic medulloblastomas. Am J Pathol 156: 433-437.

Huang H, Reis R, Yonekawa Y, Lopes JM, Kleihues P, Ohgaki H (1999). Identification in human brain tumors of DNA sequences specific for SV40 large T-antigen. Brain Pathol 9: 33-42.

Hunter DJ, Gurney EG (1994). The genomic instability associated with integrated simian virus 40 DNA is dependent on the origin of replication and early control region. J Virol 68: 787-796.

Khalili K (2001). Human neurotropic JC virus and its association with brain tumors. Dis Markers 17: 143-147.

Khalili K, Krynska B, Del Valle L, Katsetos CD, Croul S (1999). Medulloblastomas and the human neurotropic polyomavirus JC virus. Lancet 353: 1152-1153.

Knudsen ES, Wang JY (1998). Hyperphosphorylated p107 and p130 bind to T-antigen: identification of a critical regulatory sequence present in RB but not in p107/p130. Oncogene 16: 1655-1663.

Kouhata T, Fukuyama K, Hagihara N, Tabuchi K (2001). Detection of simian virus 40 DNA sequence in human primary glioblastomas multiforme. J Neurosurg 95: 96101.

Krieg P, Amtmann E, Jonas D, Fischer H, Zang K, Sauer $\mathrm{G}$ (1981). Episomal simian virus 40 genomes in human brain tumors. Proc Natl Acad Sci U S A 78: 6446-6450.

Krieg P, Scherer G (1984). Cloning of SV40 genomes from human brain tumors. Virology 138: 336-340.

Krynska B, Del Valle L, Croul S, Gordon J, Katsetos CD, Carbone M, Giordano A, Khalili K (1999a). Detection of human neurotropic JC virus DNA sequence and expression of the viral oncogenic protein in pediatric medulloblastomas. Proc Natl Acad Sci U S A 96: 11519-11524.

Krynska B, Del Valle L, Gordon J, Otte J, Croul S, Khalili K (2000). Identification of a novel p53 mutation in JCVinduced mouse medulloblastoma. Virology 274: 65-74.

Krynska B, Otte J, Franks R, Khalili K, Croul S (1999b). Human ubiquitous JCV(CY) T-antigen gene induces brain tumors in experimental animals. Oncogene 18: 39-46.

Lassak A, Del Valle L, Peruzzi F, Wang JY, Enam S, Croul $S$, Khalili K, Reiss K (2002). Insulin receptor substrate 1 translocation to the nucleus by the human JC virus T-antigen. J Biol Chem 277: 17231-17238.

Lednicky JA, Garcea RL, Bergsagel DJ, Butel JS (1995). Natural simian virus 40 strains are present in human choroid plexus and ependymoma tumors. Virology 212: 710717.

Levine AJ (1997). p53, the cellular gatekeeper for growth and division. Cell 88: 323-331.
Linet MS, Gridley G, Canttingius S, Nicholson HS, Martinsson U, Glimelius B, Adami HO, Zack M (1996). Maternal and perinatal risk factors for childhood brain tumors (Sweden). Cancer Causes Control 7: 437448.

London WT, Houff SA, Madden DL, Fuccillo DA, Gravell M, Wallen WC, Palmer AE, Sever JL, Padgett BL, Walker DL, ZuRhein GM, Ohashi T (1978). Brain tumors in owl monkeys inoculated with a human polyomavirus (JC virus). Science 201: 1246-1249.

Major EO, Vacante DA, Traub RG, London WT, Sever JL (1987). Owl monkey astrocytoma cells in culture spontaneously produce infectious. JC virus which demonstrates altered biological properties. J Virol 61: 14351441.

Malkin D, Chilton-MacNeill S, Meister LA, Sexsmith E, Diller L, Garcea RL (2001). Tissue-specific expression of SV40 in tumors associated with the Li-Fraumeni syndrome. Oncogene 20: 4441-4449.

Martini F, Iaccheri L, Lazzarin L, Carinci P, Corallini A, Gerosa M, Iuzzolino P, Barbanti-Brodano G, Tognon M (1996). SV40 early region and large T-antigen in human brain tumors, peripheral blood cells, and sperm fluids from healthy individuals. Cancer Res 56: 4820-4825.

Meinke W, Goldstein DA, Smith RA (1979). Simian virus 40-related DNA sequences in a human brain tumor. Neurology 9: 1590-1594.

Messing A, Pinkert CA, Palmiter RD, Brinster RL (1988). Developmental study of SV40 large T antigen expression in transgenic mice with choroid plexus neoplasia. Oncogene Res 3: 87-97.

Neel JV, Major EO, Awa AA, Glover T, Burgess A, Traub R, Curfman B, Satoh C (1996). Hypothesis: "Rogue cell"type chromosomal damage in lymphocytes is associated with infection with the JC human polyoma virus and has implications for oncogenesis. Proc Natl Acad Sci US A 93: 2690-2695.

Nozaki M, Tada M, Kobayashi H, Zhang CL, Sawamura Y, Abe H, Ishii N, Van Meir EG (1999). Roles of the functional loss of p53 and other genes in astrocytoma tumorigenesis and progression. Neuro-oncol 1: 124-137.

Ohsumi S, Ikehara I, Motoi M, Ogawa K, Nagashima K, Yasui K (1985). Induction of undifferentiated brain tumors in rats by a human polyomavirus (JCV). Jpn J Cancer Res 76: 429-431.

Rabson AS, O’Conor GT, Kirschstein RL, Branigan WJ (1962). Papillary ependymomas produced in Rattus (Mastomys). natalensis inoculated with vacuolating virus (SV40). J Natl Cancer Inst 765-787.

Ray FA, Peabody DS, Cooper JL, Cram LS, Kraemer PM (1990). SV40 T-antigen alone drives karyotype instability that precedes neoplastic transformation of human diploid fibroblasts. J Cell Biochem 42: 13-31.

Rencic A, Gordon J, Otte J, Curtis M, Kovatich A, Zoltick P, Khalili K, Andrews D (1996). Detection of JC virus DNA sequence and expression of the viral oncoprotein, tumor antigen, in brain of immunocompetent patient with oligoastrocytoma. Proc Natl Acad Sci U S A 93: 73527357.

Rizzo P, Bocchetta M, Powers A, Foddis R, Stekala E, Pass HI, Carbone M (2001). SV40 and the pathogenesis of mesothelioma. Semin Cancer Biol 11: 63-71.

Rushton JJ, Jiang D, Srinivasan A, Pipas JM, Robbins PD (1997). Simian virus 40 T-antigen can regulate p53mediated transcription independent of binding p53. J Virol 71: 5620-5623. 
Salewski H, Bayer TA, Eidhoff U, Preuss U, Weggen S, Scheidtmann KH (1999). Increased oncogenecity of subclones of SV40 large T-induced neuroectodermal tumor cell lines after loss of large $\mathrm{T}$ expression and concomitant mutation in p53. Cancer Res 59: 1980-1986.

Seth P, Diaz F, Major EO (2003). Advances in the biology of JC virus and induction of progressive multifocal leukoencephalopathy. J NeuroVirol 9: 236-246.

Shah KV, Daniel RW, Strandberg JD (1975). Sarcoma in a hamster inoculated with BK virus, a human papovavirus. J Natl Cancer Inst 54: 945-950.

Shah KV, Nathanson N (1976). Human exposure to SV40: review and comment. Am J Epidemiol 103: 142.

Small JA, Khoury G, Jay G, Howley PM, Scangos GA (1986). Early regions of JC virus and BK virus induce distinct and tissue-specific tumors in transgenic mice. Proc Natl Acad Sci U S A 83: 8288-8292.

Soriano F, Shelburne CE, Gokcen M (1974). Simian virus 40 in a human cancer. Nature 249: 421-424.

Staib C, Pesch J, Gerwig R, Gerber JK, Brehm U, Stangl A, Grummt F (1996). p53 inhibits JC virus DNA replication in vivo and interacts with JC virus large T-antigen. Virology 219: 237-246.

Stewart AR, Lednicky JA, Butel JS (1998). Sequence analysis of human tumor-associated SV40 DNAs and SV40 viral isolates from monkeys and humans. J NeuroVirol 4: 182-193.

Tabuchi K, Kirsch WM, Low M, Gaskin D, Van Buskirk J, Maa S (1978). Screening of human brain tumors for SV40-related T-antigen. Int J Cancer. 21: 12-17.
Uchida S, Watanabe S, Aizawa T, Furuno A, Muto T (1979). Polyoncogenicity and insulinoma-inducing ability of BK Virus, a human Papovavirus, in Syrian golden hamsters. J Natl Cancer Inst 63: 119-126.

Van Dyke TA, Finlay C, Miller D, Marks J, Lozano G, Levine AJ (1987). Relationship between simian virus 40 large tumor antigen expression and tumor formation in transgenic mice. J Virol 61: 2029-2032.

Wang JY, Del Valle L, Gordon J, Rubini M, Romano G, Croul S, Peruzzi F, Khalili K, Reiss K (2001). Activation of the IGF-IR system contributes to malignant growth of human and mouse medulloblastomas. Oncogene 20: 38573868.

Watanabe S, Kotake S, Nozawa A, Muto T, Uchida S (1982). Tumorigenicity of human BK papovavirus plaque isolates, wild-type and plaque morphology mutant, in hamsters. Int J Cancer 29: 583-586.

Weggen S, Bayer TA, von Deimling A, Reifenberger G, von Schweinitz D, Wiestler OD, Pietsch T (2000). Low frequency of SV40, JC and BK polyomavirus sequences in human medulloblastomas, meningiomas and ependymomas. Brain Pathol 10: 85-92.

Wetmore C, Eberhart DE, Curran T (2001). Loss of p53 but not ARF accelerates medulloblastoma in mice heterozygous for patched.Cancer Res 61: 513-516.

ZuRhein GM (1983). Studies of JCV-induced nervous system tumors in the Syrian hamster: a review. In: Polyomaviruses and human neurological diseases, Sever JL, Madden DL (eds.) New York: Alan R. Liss, pp 205221. 